\title{
BIOCHEMICAL CHANGES IN EARS OF WHEAT GENOTYPES SUBJECTED TO FUSARIUM SPP. ATTACK
}

\author{
Tihana MarČeK, ${ }^{1 *}$ Marija Viljevac Vuletić 2 and Valentina Španić 2 \\ ${ }^{1}$ Department of Food and Nutrition Research, Faculty of Food Technology Osijek, \\ Franje Kuhača 20, HR-31000 Osijek, Croatia \\ ${ }^{2}$ Agricultural Institute Osijek, Južno predgrađe 17, HR-31000 Osijek, Croatia
}

(Received: May 8, 2018; accepted: August 6, 2018)

\begin{abstract}
In wheat, Fusarium fungus promotes the appearance of destructive disease named as Fusarium head blight (FHB) that can cause grain yield reduction and mycotoxin accumulation. The focus of this research was to verify the influence of Fusarium graminearum and F. culmorum on wheat genotypes with different susceptibility to FHB: "Super Žitarka" (susceptible), "Lucija" (moderately resistant) and "Apache" (resistant). The experiment was performed under field conditions by artificial spore inoculation of ears at the flowering stage. The effectiveness of antioxidative enzymes, hydrogen peroxide $\left(\mathrm{H}_{2} \mathrm{O}_{2}\right)$ content and malondialdehyde (MDA) content were observed at several sampling points after Fusarium inoculation ( 3,15 and 24 hours). "Lucija" responded to pathogen by increase of guaiacol peroxidase (POD) activity, high $\mathrm{H}_{2} \mathrm{O}_{2}$ and MDA content in the early post-inoculation times ( 3 and 15 hours), compared to control. "Super Žitarka" displayed inhibition of catalase (CAT) activity throughout the whole time course of the experiment. Infected plants of "Apache" showed notable decline in MDA content over time. Moreover, in "Apache" increased $\mathrm{H}_{2} \mathrm{O}_{2}$ accumulation was observed immediately after Fusarium exposure (3 and 15 hours), compared to 24 hours. Rapid overproduction of $\mathrm{H}_{2} \mathrm{O}_{2}$ under Fusarium stress marked "Apache" as FHB-resistant.
\end{abstract}

Keywords: Enzyme antioxidative system - Fusarium spp. $-\mathrm{H}_{2} \mathrm{O}_{2}$ content - lipid peroxidation - wheat genotypes

\section{INTRODUCTION}

Plant exposure to pathogens leads to the numerous physiological and molecular changes within plant. Aside being harmful for the plant growth and development, pathogens can directly affect the production of agricultural and industrial important plants. One of the most widespread wheat disease is Fusarium head blight (FHB) caused by fungi Fusarium spp. [20]. The disease occurrence and incidence depend on environmental conditions such as humid and warm weather that promotes the spore dissemination. The most sensitive period for the plant infection is the time of flowering and early stages of seed development [9]. The first visible symptoms of FHB infection manifest as small colourless area at the base of the glume of the flower inside the inflorescence. In the later stages of infection, ears become bleached,

*Corresponding author; e-mail address: tihana.marcek@ptfos.hr 
redorange and even pink with the wrinkled, reduced-weight grains $[8,14,16]$. FHB speeding is also a health problem because infected grains may contain mycotoxins which consequently can be present in the human and animal nutrition [29].

Reactive oxygen species (ROS) are highly reactive particles that plants produce constitutively in the chloroplast, mitochondria and peroxisomes under normal physiological conditions. In such optimal conditions, their presence generally is not harmful for the cell [22]. The problem becomes greate when the plant finds itself under biotic and abiotic stress conditions resulting in increment of ROS concentration in the cell. Such extensive ROS levels impede the cellular metabolism, cause the DNA damages and disrupt the cell integrity [5]. Catalase (CAT), ascorbate peroxidase (APX) and guaiacol peroxidase (POD) are the most important antioxidative enzymes involved in the reduction of $\mathrm{H}_{2} \mathrm{O}_{2}$ to $\mathrm{H}_{2} \mathrm{O}$ [4]. POD is a multiple-role enzyme involved mostly in the processes related with the cell wall modifications such as cross-linking of the structural proteins, lignification, suberization and cell elongation but also has a protective role in plant-pathogen interactions [2]. Polyphenol oxidase (PPO) as a part of non-enzymatic antioxidative mechanism is involved in a defence response provoked by pathogen [18]. Induced activity of the antioxidative system together with the non-enzymatic pathways appeared to be an important indicator for disease resistance $[13,25]$. In contrast, ROS production can be beneficial for the plant immunity. Immediately after the pathogen attached to the plant surface, it triggers the rapid production of huge amounts of ROS, especially hydrogen peroxide $\left(\mathrm{H}_{2} \mathrm{O}_{2}\right)$ in the specific reaction called "oxidative burst". Such an early event during incompatible plant-pathogen interaction occurs in order to prevent the pathogen entrance and spreading $[15,38,39]$.

In our previous study, we tested the response of several wheat genotypes to FHB and noted that FHB-resistant genotype had quicker response to infection [34]. For this reason the objective of this study was to complete our previously published results by examining the response of three wheat genotypes "Super Žitarka" (FHB-sensitive), "Lucija" (FHB-moderately resistant) and "Apache" (FHB-resistant) to Fusarium infection, in order to verify whether there are any differences in their physiological response to infection. Furthermore, we want to explore which defence mechanisms contribute to FHB resistance.

\section{MATERIALS AND METHODS}

\section{Inoculum production}

Macroconidial inoculum was used for FHB disease screening in the Osijek field experiment in 2016. The inoculum was a combination of two isolates $(50: 50)$ consisted of $F$. graminearum, isolated from wheat loved in Croatia and F. culmorum was obtained from the Department of Biotechnology, IFA-Tulln, Austria. Inoculum was produced and quantified according to Lemmens et al. [17] and Snijders et al. [30], with minor modifications. The final concentration was set up to $1 \times 10^{5} \mathrm{ml}^{-1}$. 


\section{Plant material and treatment}

In the first part of field experiments, ears of wheat genotypes were treated with the mixture of spore suspension while second part of experiment were control plants exposed to natural infection. Spray inoculations were carried out in the stage of flowering (Zadok's scale 65) [40]. All experiments (both control and infected) were repeated twice. For physiological and biochemical assays, plant tissue was collected after at 3,15 and 24 hours and stored at $-80{ }^{\circ} \mathrm{C}$ prior to analyses. The percentage of bleached spikelets (disease intensity) per plot was estimated according to a linear scale $(0-100 \%)$ at $10,14,18,22$ and 26 days after inoculation. With this data, the area under disease progress curve (AUDPC) for FHB incidence was calculated for each entry [28]. FHB incidence per plot was considered as a measure for general resistance (GR). Disease incidence was used as an indicator for Type I+II resistance. The percentage of diseased heads was calculated after assessing a random sample of 30 heads on 10,14, 18, 22 and 26 days after inoculation. AUDPC for FHB incidence was calculated. After ripening, a sample of 50 ears per subplot was harvested manually and weighed. After threshing grains were weighed and the percentage of kernels infected with Fusarium (\% FCK) was assessed. For the determination of \% FCK, 100 kernels of each genotype were randomly selected and incubated at $25^{\circ} \mathrm{C}$ at a relative air humidity of $80 \%$. After the 6th day of incubation, the percentage of Fusarium infected grains was calculated.

\section{Enzyme extraction}

Five ears of treated and non-treated (biological repetitions) plots were collected at each time point and pulled. Ears were ground by addition of polyvinylpolypyrrolidone (PVP), using pestle and mortar. Tissue $(200 \mathrm{mg})$ was homogenized in $1 \mathrm{ml}$ ice cold $50 \mathrm{mM}$ potassium phosphate buffer $(\mathrm{pH} 7.0)$ containing $0.1 \mathrm{mM}$ ethylenediaminetetraacetic acid (EDTA) and $5 \mathrm{mM}$ ascorbate acid and centrifuged at $14,000 \mathrm{~g}$ for $15 \mathrm{~min}$ at $4{ }^{\circ} \mathrm{C}$. Subsequently, re-extraction of tissue was done again with addition $1 \mathrm{~mL}$ of same buffer and obtained supernatants were used for protein concentration determination and assays of antioxidative enzyme activities. The protein concentration was measured using bovine serum albumin as a standard [7]. The activity of enzymes was expressed as units (U) per milligram of proteins [U mg ${ }^{-1}$ proteins].

\section{Assays of antioxidant enzyme activities}

POD [Enzyme Commission number (EC) 1.11.1.7] activity was measured at $470 \mathrm{~nm}$ as an increase in absorbance as a result of guaiacol (Sigma) oxidation [27]. The reaction mixture contained $0.2 \mathrm{mM}$ potassium phosphate buffer ( $\mathrm{pH} 5.8), 5 \mathrm{mM}$ guaiacol and $5 \mathrm{mM} \mathrm{H}_{2} \mathrm{O}_{2}$. The reaction started by addition $25 \mu \mathrm{L}$ of extract to $975 \mu \mathrm{L}$ of reac- 
tion mixture. APX (EC 1.11.1.1) was obtained by tracking the decline in absorbance of ascorbate at $290 \mathrm{~nm}$ [21]. The reaction started by addition of $10 \mu \mathrm{L} 12 \mathrm{mM} \mathrm{H}_{2} \mathrm{O}_{2}$ to $990 \mu \mathrm{L}$ reaction solution contained $50 \mathrm{mM}$ potassium phosphate buffer ( $\mathrm{pH} 7.0$ ), $10 \mu \mathrm{L} 25 \mathrm{mM}$ ascorbate acid, $25 \mu \mathrm{L}$ and $0.1 \mathrm{mM}$ EDTA. CAT activity (EC 1.11.1.6) was estimated as decline in absorbance at $240 \mathrm{~nm}$ [1]. The reaction mixture consisted of $50 \mathrm{mM}$ potassium phosphate buffer ( $\mathrm{pH} 7.0)$ and $5 \mathrm{mM} \mathrm{H}_{2} \mathrm{O}_{2}$. Enzymatic decomposition of $\mathrm{H}_{2} \mathrm{O}_{2}$ occurred after addition of $50 \mu \mathrm{L}$ of extract to $950 \mu \mathrm{L}$ of reaction mixture. The activity of PPO (EC 1.14.18.1) was determined as an increase of absorbance at $430 \mathrm{~nm}$ as a result of breakdown of pyrogallol to o-quinones at $40{ }^{\circ} \mathrm{C}$ [26]. Reaction started by adding $15 \mu \mathrm{L}$ of extract to reaction mixture $(2 \mathrm{~mL})$ consisted of $100 \mathrm{mM}$ potassium phosphate buffer $(\mathrm{pH} 7.0)$ and $0.2 \mathrm{~mL} 100 \mathrm{mM}$ pyrogallol.

\section{Level of lipid peroxidation and $\mathrm{H}_{2} \mathrm{O}_{2}$ concentration}

For lipid peroxidation and $\mathrm{H}_{2} \mathrm{O}_{2}$ content measurements ears tissue was collected in the same way as for the determination of enzyme activity. $400 \mathrm{mg}$ of fine powder was homogenized in $2 \mathrm{~mL}$ of $0.1 \%(\mathrm{w} / \mathrm{v})$ trichloroacetic acid (TCA), centrifuged at $12,000 \mathrm{~g}$ for $15 \mathrm{~min}$ at $4{ }^{\circ} \mathrm{C}$. Malondialdehyde (MDA) content, a final product of decomposition of biomembranes was measured [37]. $1 \mathrm{~mL}$ of $0.5 \%(\mathrm{w} / \mathrm{v})$ thiobarbituric acid (TBA) in $20 \%$ TCA was added to $0.5 \mathrm{~mL}$ of supernatant, heated at $95{ }^{\circ} \mathrm{C}$ for $30 \mathrm{~min}$, cooled immediately in an ice bath and centrifuged at $14,000 \mathrm{~g}$ for $15 \mathrm{~min}$ at $4{ }^{\circ} \mathrm{C}$. The absorbance of supernatant was measured at $532 \mathrm{~nm}$ for non-specific turbidity by subtracting the absorbance at $600 \mathrm{~nm}$. As a blank $0.5 \%$ TBA in $20 \%$ TCA solution was used. Level of lipid peroxidation was expressed as MDA in nanomols per gram of fresh weight [nmol g-1 $\mathrm{FW}$ ], using an extinction coefficient of $155 \mathrm{mM}^{-1}$ $\mathrm{cm}^{-1}$. For the determination of $\mathrm{H}_{2} \mathrm{O}_{2}$ content, $0.5 \mathrm{~mL}$ of supernatant was added in mixture of $1 \mathrm{M} \mathrm{KI}$ and $10 \mathrm{mM}$ potassium phosphate buffer $(\mathrm{pH} \mathrm{7.0)}$ and left in dark conditions [36]. After $20 \mathrm{~min}$, the absorbance was recorded at $390 \mathrm{~nm}$ and $\mathrm{H}_{2} \mathrm{O}_{2}$ content was determined using calibration curve and expressed as nanomoles per gram of fresh weight $\left[\mathrm{nmol} \mathrm{g}^{-1} \mathrm{FW}\right]$.

\section{Statistical analysis}

All results (enzymatic activity, MDA and $\mathrm{H}_{2} \mathrm{O}_{2}$ content) were expressed as means of five (technical repetitions) with the corresponding standard errors $( \pm \mathrm{SE})$. The data were analysed by ANOVA. Differences between means were compared by the posthoc Duncan's test at the 0.05 probability level. Data were analysed by STATISTICA 13.1 (Stat Soft Inc., USA) software package. 


\section{RESULTS}

The AUDPC for general resistance (Fusarium severity) in Apache (1.25) was lower in comparison to Lucija (50.8) and Super Žitarka (87.5) (Table 1). The Fusarium colonised kernels showed a similar trend in inoculated plants, where Super Žitarka showed $25 \%$ of colonized kernels in comparison to Apache (3\%) (Table 1). For Lucija and Super Žitarka, there was a significant increase in symptoms at 22 days (days after inoculation) (Table 2). The Fusarium incidence increased from 13.1 to $45.0 \%$ for Lucija and from 16.7 to $58.0 \%$ for Super Žitarka from 22 to 26 days.

In treated plants of "Lucija", POD activity increased after 3 hours compared to control (Table 3b). In "Lucija", POD showed higher activity immediately after the inoculation $(3 \mathrm{~h})$ in comparison to 15 and 24 hours while in "Super Žitarka" POD activity was inhibited at 15 hours in regard to 3 and 24 hours (infected plants) (Tables 3a, 3b).

In all sampling points (3, 15 and 24 hours) infected plants of "Super Žitarka" showed decreased CAT activity, compared to untreated plants, while at 24 hours "Apache" had the same response to Fusarium stress (Tables 3a, 3c).

Table 1

AUDPC for general resistance (A), Type I+ II resistance (initial infection) to FHB (B) and Fusarium colonized kernels for three wheat varieties (C)

\begin{tabular}{|c|c|c|c|c|}
\hline Genotype & (A) & (B) & (C) (\%) & Resistance/susceptibility* \\
\hline "Apache" & 1.25 & 20.81 & 3 & $\mathrm{R}$ \\
\hline "Lucija" & 50.75 & 137.45 & 18 & $\mathrm{MR}$ \\
\hline "Super Žitarka" & 87.50 & 164.14 & 25 & $\mathrm{~S}$ \\
\hline
\end{tabular}

*R - resistant; MR - moderate resistant; $\mathrm{S}$ - susceptible.

Table 2

Disease symptoms and diseased ears for general resistance for Type I+II after 10, 14, 18, 22 and 26 days $(\mathrm{d})$

\begin{tabular}{|c|c|c|c|c|c|}
\hline \multirow{2}{*}{ Genotype } & \multicolumn{5}{|c|}{ Disease symptoms (\%) } \\
\cline { 2 - 6 } & $10 \mathrm{~d}$ & $14 \mathrm{~d}$ & $18 \mathrm{~d}$ & $22 \mathrm{~d}$ & $26 \mathrm{~d}$ \\
\hline "Super Žitarka" & 0 & 0 & 5 & 12.5 & 40 \\
\hline "Lucija" & 0 & 0 & 1.5 & 5 & 27.5 \\
\hline "Apache" & 0 & 0 & 0 & 0.5 & 0.5 \\
\hline "Super Žitarka" & $10 \mathrm{~d}$ & $14 \mathrm{~d}$ & $18 \mathrm{~d}$ & $22 \mathrm{~d}$ & $26 \mathrm{~d}$ \\
\hline & 0 & 8.33 & 11.665 & 16.66 & 58.33 \\
\hline "Lucija" & 3.33 & 3.33 & 9.995 & 13.33 & 44.995 \\
\hline
\end{tabular}



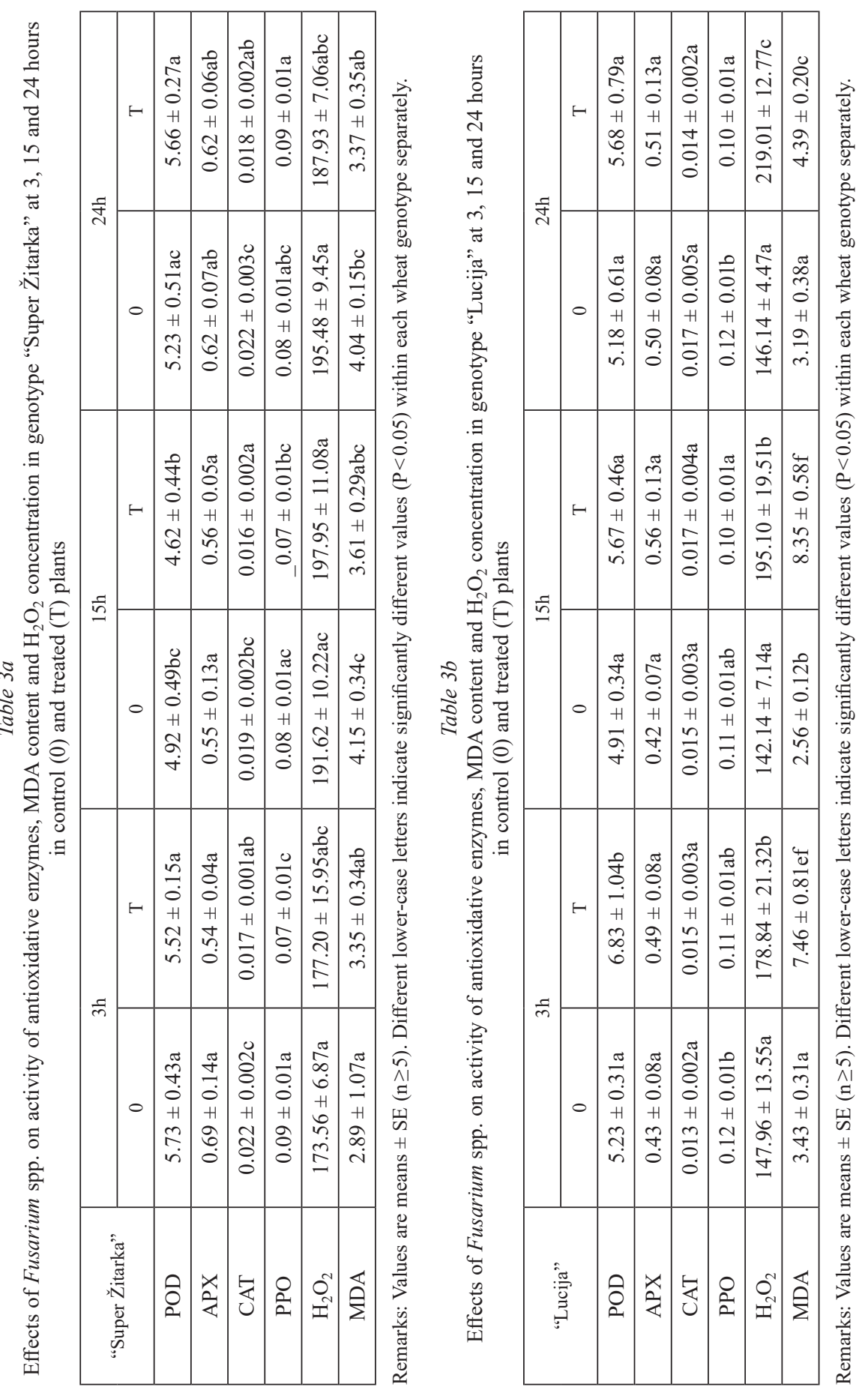


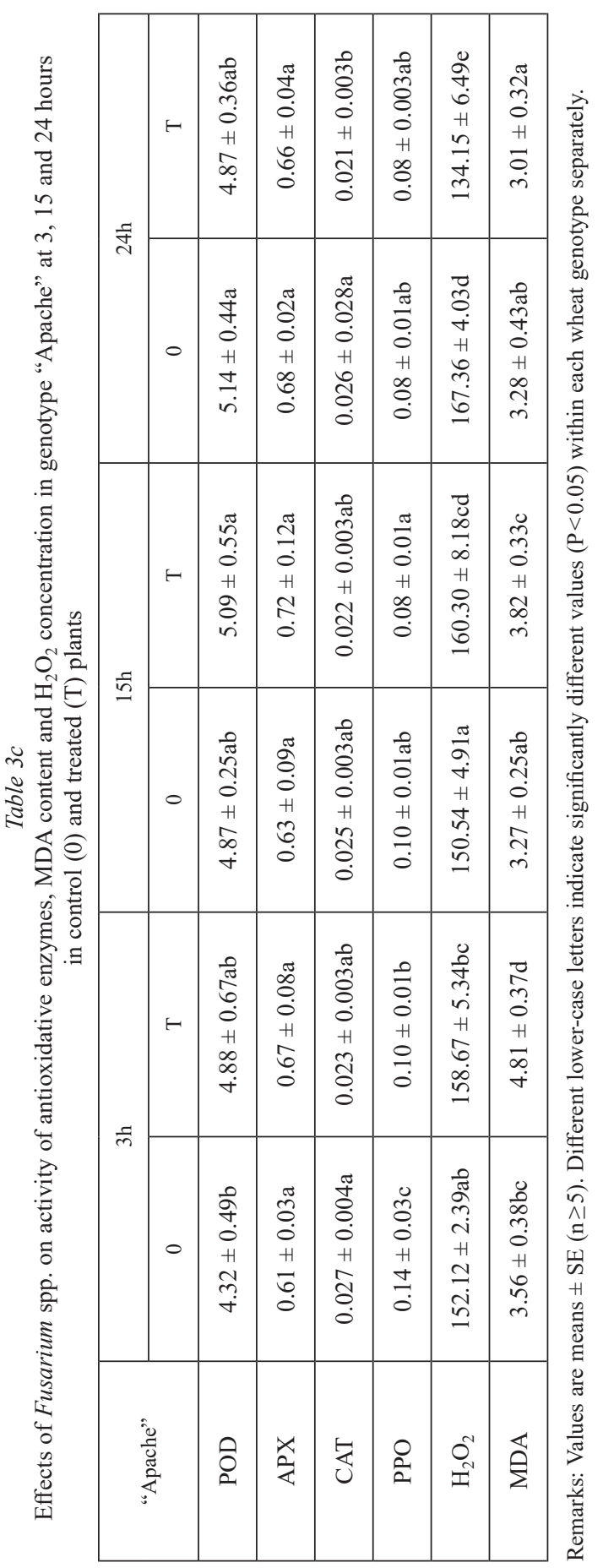

Acta Biologica Hungarica 69, 2018 
For APX activity no significant interactions were noticed in infected plants (all P-values $>0.05$ ) (Tables 3a-c).

Considering PPO activity, Duncan test showed a significant interaction between genotype and experimental period under control conditions $(\mathrm{P}=0.001725)$ and Fusarium stress $(\mathrm{P}=0.0035)$. "Super Žitarka" exhibited after 3 hours decreased PPO activity, compared to untreated plants (Table 3a). The same genotype showed decreased PPO activity under treatment both after 3 and 15 hours, compared to 24 hours.

Considering MDA content, in "Apache" and "Lucija", the time had a significant influence on treatment $(\mathrm{P}<0.0001)$. Fusarium treated plants of "Lucija" showed increased MDA content at each point of collection (3, 15 and 24 hours) in regard to respective control plants while "Apache" showed increase in MDA content in comparison to untreated plants at 3 and 15 hours (Tables 3b, 3c). "Lucija" under pathogen infection exhibited the highest MDA content after 15 hours, compared to 24 hours, and increased MDA content after 3 hours, compared to treatment for 24 hours. Infected plants of "Apache" revealed a decline in MDA content at 15 and 24 hours compared to treatment for 3 hours, but higher MDA content at 15 hours than at 24 hours after treatment.

Regarding of $\mathrm{H}_{2} \mathrm{O}_{2}$ content Duncan test showed significant interaction between genotype and time of exposure under control conditions $(\mathrm{P}=0.003651)$ and Fusarium treatment $(\mathrm{P}=0.000044)$. Treated plants of "Lucija" showed significantly higher $\mathrm{H}_{2} \mathrm{O}_{2}$ concentration than control at all time points $(3,15$ and 24 hours) of treatment (Table 3b). Furthermore, at 24 hours, $\mathrm{H}_{2} \mathrm{O}_{2}$ content increased in comparison to 3 or 15 hours. Stressed-plants of "Apache" showed higher $\mathrm{H}_{2} \mathrm{O}_{2}$ content in treated plants, at 15 hours compared to control, and decreased $\mathrm{H}_{2} \mathrm{O}_{2}$ concentration under infection compared to control at 24 hours (Table 3c).

\section{DISCUSSION}

The lower Fusarium symptoms in "Apache" compared to "Lucija" and "Super Žitarka" confirmed the variation in resistance, which ranked them as resistant ("Apache"), moderately resistant ("Lucija") and susceptible ("Super Žitarka") to FHB [12, 33].

Increased expression of POD activity under pathogen attack generates the toxic ambience for the fungi growth through rapid oxidative burst reaction $[3,24]$. "Lucija" showed remarkable POD activity immediately after the inoculation (at 3 hours), in comparison to control, referring that in this genotype POD perhaps had an important role in early defence response to Fusarium. Diseased plants of "Lucija" also showed remarkable $\mathrm{H}_{2} \mathrm{O}_{2}$ accumulation at all time-points, compared to control. Moreover, in "Apache" increased $\mathrm{H}_{2} \mathrm{O}_{2}$ accumulation was observed immediately after Fusarium exposure (at 3 and 15 hours), compared to that observed after 24 hours. Such a response might be connected to the formation of the natural barrier against Fusarium penetration at the beginning of the spore infestation. A similar result was found in 
FHB-partially resistant wheat genotype "Gaskozhen", which responded to Fusarium graminearum and F. culmorum by enhanced production of $\mathrm{H}_{2} \mathrm{O}_{2}$ and high induction of POD [13]. On the other hand, induced POD activity detected in "Lucija" after Fusarium attack could be the result of the "oxidative burst". Studies aimed at the intensity of oxidative burst in plants exposed to fungi elicitors demonstrated that the host response to the elicitor showed a delayed reaction (after 8-12 hours) in the manner of ROS generation, but the visible symptoms were already notable after 2-4 hours $[11,38]$. Moreover, high $\mathrm{H}_{2} \mathrm{O}_{2}$ levels appear to inactivate CAT and APX activities referring them as less effective in $\mathrm{H}_{2} \mathrm{O}_{2}$ removal. Based on this observation we conclude that in "Lucija" Fusarium promotes an oxidative burst, which is a crucial event in compatible host-pathogen interaction. A correlation between ROS generation in host cells infected by necrotrophic fungi and pathogen survival was also observed [13]. In the same study, after experimental induction of oxidative burst by glucose/ glucose oxidase treatment in wheat leaves, the increase of $\mathrm{H}_{2} \mathrm{O}_{2}$ and $\mathrm{O}_{2}{ }^{-}$concentration caused cell death, providing thus nutrition for the pathogen.

Considering the MDA content, partially FHB-resistant "Lucija" revealed increased MDA values, compared to the untreated group, through the whole time course of the experiment, which is likely connected with the remarkable increase of $\mathrm{H}_{2} \mathrm{O}_{2}$ concentration and indicates that rapid oxidative explosion caused the destruction of membranes leading to cell death. Although "Lucija" showed great POD activity under infection (especially at 3 hours after treatment), its expression cannot be linked with Fusarium resistance due to extensive MDA content. Increased MDA content and remarkably higher $\mathrm{H}_{2} \mathrm{O}_{2}$ accumulation was also noticed in FHB-sensitive wheat cultivar "Falat" and the FHB-resistant wheat cultivar "Sumai3" subjected to F. graminearum [31].

Inoculation of "Super Žitarka" with Fusarium spores revealed inhibition of CAT activity after 3, 15 and 24 hours, of the treatment and of the PPO activity 3 hours, after the spore addition, compared to control group, suggesting that CAT and PPO activity levels may be associated both with sensitivity and disease symptoms. The link between disease appearance (caused by Pseudomonas syringae pv tomato) and PPO was described in transgenic tomato genotypes with both enhanced or reduced PPO activity [35]. PPO-supressed tomato genotypes had more pronounced disease symptoms, while PPO-enhanced genotypes showed small disease occurrence.

Agent of being involved in ROS generation under different environmental stress factors in order to improve the pro-antioxidative activity of plant, the role of PPO has also been connected with non-enzymatic plant defence response against a pathogen $[6,23]$. In infected plants of "Apache" PPO and CAT activity decreased after 3 hours and 24 hours, compared to control group. Moreover, $\mathrm{H}_{2} \mathrm{O}_{2}$ content increased in "Apache" (at 15 hours), compared to the control, but at the last time point of treatment (24 hours) it decreased, suggesting possible changes in the regulatory pathways. Namely, in response to pathogen plant restricts its entrance by stomata closure regulated by salicylic acid (SA), which may evoke the inhibition of CAT and APX activity, increasing thus $\mathrm{H}_{2} \mathrm{O}_{2}$ accumulation [10]. Inhibition of CAT activity under exposure of FHB-resistant wheat genotype "Sumai3" to F. graminearum crude extract was 
also noticed by Soranhinobar et al. [32]. However, in spite of enzymes inhibition, "Apache" was able to prevent somehow the membrane damages under infection, which is reflected by the decline of MDA content. The observation leads to the conclusion that in the FHB-resistant "Apache" the antioxidative system is not involved in the defence response. However a different observation was reported in our previous work where we pointed out the importance of early response of antioxidative system in developing FHB-resistance [34]. Such differences in the resistance reaction of FHB-resistant, wheat genotypes could be ascribed to different biological properties of the Fusarium races. It was shown that aggressiveness of $F$. graminearum isolates showed a high level of genetic variations even in samples that were growing at same field location [19].

\section{CONCLUSIONS}

Our study revealed various physiological responses of wheat genotypes with different genetic backgrounds to Fusarium. In spite of rapid induction of POD (at 3 hours) and increased $\mathrm{H}_{2} \mathrm{O}_{2}$ accumulation over time, compared to control, moderately FHBresistant genotype "Lucija" cannot be characterized as FHB-resistant due to the high MDA content. Exposure of FHB-resistant genotype to Fusarium sp. showed higher $\mathrm{H}_{2} \mathrm{O}_{2}$ accumulation at the beginning of treatment (at 3 and 15 hours), compared to a 24-hour treatment. These findings show that a resistant genotype reacts more promptly to FHB disease. FHB-susceptible genotype "Super Žitarka" under infection showed decline in CAT activity, compared to control (at in all XXXX points), suggesting its inefficiency in responding to biotic stress caused by Fusarium.

\section{ACKNOWLEDGEMENTS}

This work was supported by the Croatian Science Foundation under grant No. HRZZ-UIP-2014-9188.

\section{REFERENCES}

1. Aebi, H. (1984) Catalase in vitro. Methods Enzymol. 105, 121-126.

2. Almagro, L., Ros, G., Belchi-Navarro, S., Bru, R., Barceló, A. R., Pedren, M. A. (2009) Class III peroxidases in plant defence reactions. J. Exp. Bot. 60, 377-390.

3. Anjum, T., Fatima, S., Amjad, S. (2012) Physiological changes in wheat during development of loose smut. Trop. Plant Pathol. 37, 102-107.

4. Apel, K., Hirt, H. (2004) Reactive oxygen species: Metabolism, oxidative stress and signal transduction. Ann. Rev. Plant Biol. 55, 373-399.

5. Bandeoğlu, E., Eyidoğan, F., Yucel, M., Oktem, A. H. (2004) Antioxidant responses of shoots and roots of lentil to NaCl-salinity stress. Plant Growth. Regul. 42, 69-77.

6. Boeckx, T., Winters, A. L., Webb, K. J., Kingston-Smith, A. H. (2015) Polyphenol oxidase in leaves: is there any significance to the chloroplastic localization? J. Exp. Bot. 66, 3571-3579.

7. Bradford, M. M. (1976) A rapid and sensitive method for the quantitation of microgram quantities of protein utilizing the principle of protein-dye binding. Anal. Biochem. 72, 248-254. 
8. Brown, D. W., McCormick, S. P., Alexander, N. J., Proctor, R. H., Desjardins, A. E. (2002) Inactivation of a cytochrome P-450 is a determinant of trichothecene diversity in Fusarium species. Fungal Genet. Biol. 36, 224-233.

9. Gilbert, J., Tekauz, A. (2000) Review: recent developments in research on Fusarium head blight of wheat in Canada. Can. J. Plant Pathol. 22, 1-8.

10. Hernández, A. J., Diaz-Vivancos, P., Barba-Espín, G., Clemente-Moreno, M. J. (2017) On the role of salicylic acid in plant in responses to environmental stresses. In: Nazar, R., Iqbal, N., Khan, N. A. (eds) Salicylic acid: A multifaceted hormone. Springer, Singapore, pp. 17-34.

11. Hammond-Kosack, K. E., Jones, J. D. G. (1996) Resistance gene-dependent plant defense responses. Plant Cell. 8, 1773-1791.

12. Holzapfel, J., Voss, H. H., Miedaner, T., Korzun, V., Häberle, J., Schweizer, G., Mohler, V., Zimmermann, G., Hartl, L. (2008) Inheritance of resistance to Fusarium head blight in three European winter wheat populations. Theor. Appl. Genet. 117, 1119-1128.

13. Khaledi, N., Taheri, P., Falahati-Rastegar, M. (2016) Reactive oxygen species and antioxidant system responses in wheat cultivars during interaction with Fusarium species. Australas. Plant Pathol. 45, 653-670.

14. Kosová, K., Vítámvás, P., Prášil, I. T. (2014) Proteomics of stress responses in wheat and barleysearch for potential protein markers of stress tolerance. Front. Plant Sci. 5, 1-14.

15. Kuzniak, E., Urbanek, H. (2000) The involvement of hydrogen peroxide in plant responses to stresses. Acta Physiol. Plant. 22, 195-203.

16. Lee, T., Han, Y. K., Kim, K. H., Yun, S. H., Lee, Y. W. (2002) Tri13 and tri7 determine deoxynivalenol and nivalenol producing chemotypes of Gibberella zeae. Appl. Environ. Microbiol. 68, 21482154.

17. Lemmens, M., Hoursm, K., Lew, H., Ruckenbauer, P. (2004) The effect of nitrogen fertilization on Fusarium head blight development and deoxynivalenol contamination in wheat. Phytopathology 152, $1-8$

18. Madadkhah, E., Lotfi, M., Nabipour, A., Rahmanpour, S., Banihashemi, Z., Shoorooei, M. (2012) Enzymatic activities in roots of melon genotypes infected with Fusarium oxysporum f. sp. melonis race 1. Sci. Hortic. 135, 171-176.

19. Mahmoud, A. F. (2016) Genetic variation and biological control of Fusarium graminearum isolated from wheat in Assiut-Egypt. Plant Pathol. J. 32, 145-156.

20. McIntosh, R. A. (1998) Breeding wheat for resistance to biotic stresses. Euphytica 100, 19-34

21. Nakano, Y., Asada, K. (1981) Hydrogen peroxide is scavenged by ascorbate - specific peroxidase in spinach chloroplasts. Plant Cell Physiol. 22, 867-880.

22. Nanda, A. K., Andrio, E., Marino, D., Pauly, N., Dunand, C. (2010) Reactive oxygen species during plant - microorganism early interactions. J. Integr. Plant Biol. 52, 195-204.

23. Parveen, I., Threadgill, M. D., Moorby, J. M., Winters, A. (2010) Oxidative phenols in forage crops containing polyphenol oxidase enzymes. J. Agri. Food Chem. 58, 1371-1382.

24. Passardi, F., Cosio, C., Penel, C., Dunand, C. (2005) Peroxidases have more functions than a swiss army knife. Plant Cell Rep. 24, 255-265.

25. Racchi, M. L. (2013) Antioxidative defenses in plants with attention to Prunus and Citrus spp. Antioxidants 2, 340-369.

26. Raymond, J., Rakariyatham, N., Azanza, J. (1993) Purification and some properties of polyphenoloxidase from sunflower seeds. Phytochemistry 34, 927-931.

27. Siegel, B. Z., Galston, W. (1967) The isoperoxidases of Pisum sativum. Plant Physiol. 42, $221-226$.

28. Shaner, G., Finney, R. E. (1977) The Effect of nitrogen fertilization on the expression of slow mildewing resistance in knox wheat. Phytopathology 67, 1051-1056.

29. Shepard, G. C. (2011) Fusarium mycotoxins and human health. Plant Breeding Seed Sci. 64, $113-121$.

30. Snijders, C. H. A., Van Eeuwijk, F. A. (1991) Genotype X strain interactions for resistance to Fusarium head blight caused by Fusarium culmorum in winter wheat. Theor. Appl. Genet. 81, 239244 
31. Sorahinobar, M., Niknam, V., Ebrahimzadeh, H., Soltanloo, H., Moradi, B., Bahram, M. (2016) Lack of association between Fusarium graminearum resistance in spike and crude extract tolerance in seedling of wheat. Eur. J. Plant Pathol. 144, 525-538.

32. Soranhinobar, M., Soltanloo, H., Niknam, V., Ebrahimzadeh, H., Moradi, B., Safaie, N., Behmanesh, M., Bahram, M. (2017) Physiological and molecular responses of resistant and susceptible wheat cultivars to Fusarium graminearum mycotoxin extract. Can. J. Plant Pathol. 39, 444-453.

33. Španić, V., Lemmens, M., Drezner, G. (2013) Variability of components of Fusarium head blight resistance among wheat genotypes. Cereal Res. Commun. 41, 420-430.

34. Španić, V., Viljevac Vuletić, M., Abičić, I., Marček, T. (2017) Early response of wheat antioxidant system with special reference to Fusarium head blight stress. Plant Physiol. Biochem. 115, 34-43.

35. Thipyapong, P., Hunt, M. D., Steffens, J. C. (2004) Antisense downregulation of polyphenol oxidase results in enhanced disease susceptibility. Planta 220, 105-117.

36. Velikova, V., Yordanov, I., Edreva, A. (2000) Oxidative stress and some antioxidant systems in acid rain-treated bean plants: protective role of exogenous polyamines. Plant Sci. 151, 59-66.

37. Verma, S., Dubey, R. S. (2003) Leads toxicity induces lipid peroxidation and alters the activities of antioxidant enzymes in growing rice plants. Plant Sci. 164, 645-655.

38. Wojtaszek, P. (1997) Oxidative burst: an early plant response to pathogen infection. Biochem. J. 322, 681-692.

39. Yoshioka, H., Bouteau, F., Kawano, T. (2008) Discovery of oxidative burst in the field of plant immunity. Plant Signal Behav. 3, 153-155.

40. Zadoks, J. C., Chang, T. T., Konzac, F. C. (1974) A decimal code for the growth stages of cereals. Weed Res. 14, 415-421. 